\title{
Gender influences decisions to change land use practices in the tropical forest margins of Jambi, Indonesia
}

\author{
Grace B. Villamor • Febrina Desrianti • \\ Ratna Akiefnawati • Sacha Amaruzaman • \\ Meine van Noordwijk
}

Received: 19 February 2013 / Accepted: 14 May 2013 / Published online: 20 July 2013

(C) The Author(s) 2013. This article is published with open access at Springerlink.com

\begin{abstract}
This study explores the role of gender as a factor in decision making about alternative land use options and in responses to new investment opportunities, which has received little attention to date. An observational study to determine the different factors affecting male and female decisions to change land use at the individual level in a forest margin landscape in Jambi (Sumatra, Indonesia) was combined with a set of role playing games (RPGs) designed to assess participant responses in a simulated social setting of women-only and men-only groups. The RPG included simulated agents offering new opportunities to convert or conserve agroforest. In the study area, rubber (Hevea braziliensis) agroforests that support high biodiversity and carbon storage are giving way to monoculture rubber and oil palm (Elaeis guineensis) plantations. When women from both the upland and lowland villages played the RPGs, external investors proposing logging or oil palm conversion were approached very positively and the resulting land use change was more dynamic and extensive than in the equivalent men-only groups. Consequently, women outperformed men in achieving income targets. In lowland areas gender is strongly associated with land use change, while in the uplands the level of conservation awareness plays a more crucial role in the maintenance of rubber agroforests. Based on the data, and contrary to expectations and gender stereotypes, it is expected that the greater involvement of women in landscape level decision making will increase emissions from deforestation and forest degradation in the area, posing further challenges to efforts to reduce such emissions.
\end{abstract}

Keywords Decision making $\cdot$ Emergence $\cdot$ Income differentiation $\cdot$ Matrilineal system $\cdot$ Roleplaying games $\cdot$ Rubber agroforests $\cdot$ REDD +

G. B. Villamor $(\triangle)$

Department of Ecology and Natural Resource Management, Center for Development Research (ZEF), University of Bonn, Walter-Flex St. 3, 53113 Bonn, Germany

e-mail: gracev@uni-bonn.de

G. B. Villamor $\cdot$ F. Desrianti $\cdot$ R. Akiefnawati $\cdot$ M. van Noordwijk

World Agroforestry Centre (ICRAF) - Southeast Asia Regional Office, JI. CIFOR, Situ Gede, Bogor, Indonesia

S. Amaruzaman

Environmental System Analysis Group, Wageningen University, Wageningen, the Netherlands 


\section{Introduction}

The expansion of crop and pastoral land into (semi-)natural ecosystems is currently the most prevalent form of land use change; it usually involves deforestation and/or forest degradation (Lambin and Meyfroidt 2011). Indonesia has experienced massive land conversion from lowland forests to intensive commercial agriculture (Rudel et al. 2009; van Noordwijk et al. 2012; Villamor et al. under review), and reports the second highest rate of deforestation (measured using an untouched natural forest definition) among tropical countries (Margono et al. 2012). This expansion generally leads to a decrease in terrestrial carbon stocks, consequently causing higher carbon emissions, along with a loss of biodiversity and changes to hydrological functions. Efforts to Reduce Emissions from Deforestation and Degradation $(\mathrm{REDD}+)$ must address the drivers of these conversion processes in order to provide leverage for a move away from business as usual. However, knowledge concerning the different ways in which men and women living in tropical forest margins respond to new opportunities to enhance or reduce emissions remains insufficient for the purpose of analyzing their respective decision making processes and actions in response to information from external agents. Owing to economic liberalization and globalization, people increasingly choose how they use the land based upon options and influences originating outside their communities. This has major implications for transitions to sustainability. This type of gender analysis has not been adequately studied to date. The present study contextualizes the changes in Sumatran land use/land cover through an examination of men and women's respective responses to new land use opportunities that may affect carbon emissions. In this study, three dimensional variables that can affect the diversity of responses between females and males are explored: 1) the elevation gradient (lowland versus upland); 2) responses of individuals and in group settings; and 3) the level of conservation awareness. In this research, it is argued that gender is one of several key elements that affect decision making and practical choices in relation to land use change. At the same time, through the use of a multi-method approach, we can describe how land use change is an emergent property of each individual's decision making process (Fig. 1).
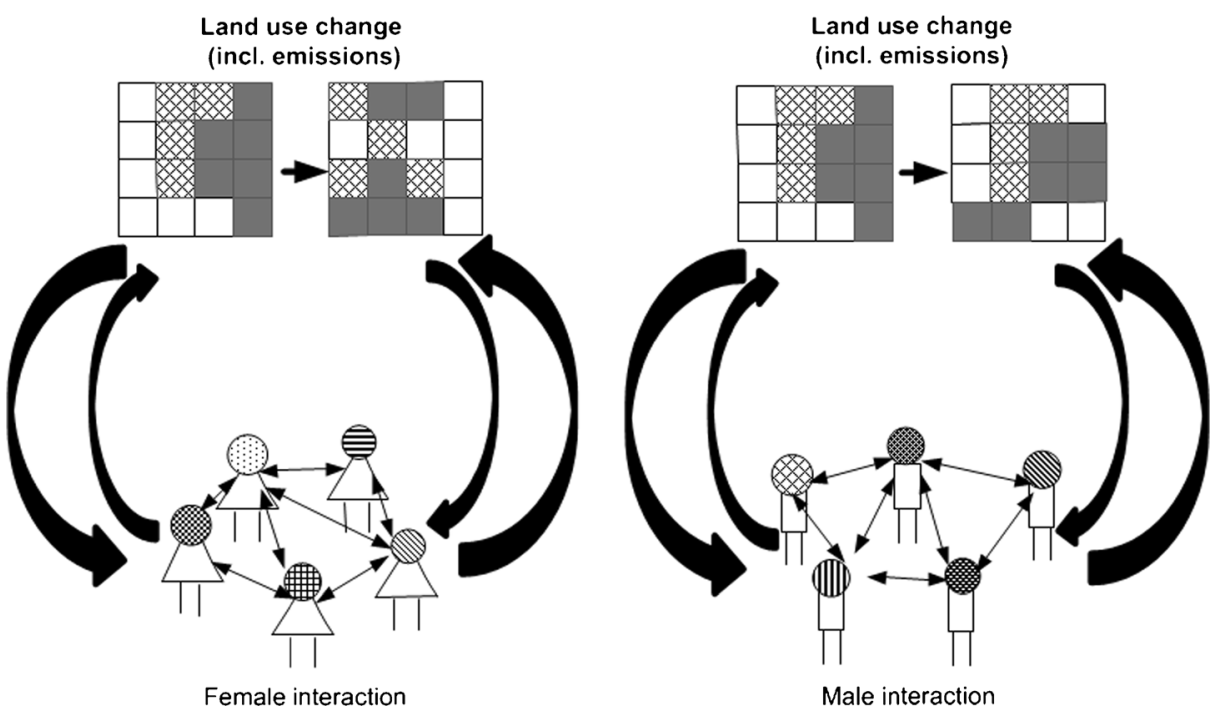

Fig. 1 Graphical abstract showing local interaction leads to emergent property e.g. land use change pattern 


\subsection{Gender, land use and REDD+}

A growing body of literature attests to the inequity between men and women in terms of access to decision making relating to resource management, land use and climate change negotiations (Denton 2002; Peach Brown 2011; Terry 2009). In many parts of the world, women have a relatively limited level of involvement in resource management in general. This is shown, for example, in the majority of studies on gender and community-based forest management, which focus on the factors affecting women's participation, their bargaining power to improve the quality of participation, and the sustainability implications of participation, mainly in an Indian or Nepalese contexts (Mai et al. 2011). Women have also had limited participation in discussions on issues of climate change and REDD+(Peach Brown 2011). Despite the increase in the participation of women at international climate summits, policy forums, and in forest resource negotiations, women's voices in the decision process at local and national levels remains limited (Hemmati and Röhr 2009; Peach Brown 2011; Terry 2009). As such, recent literature has advocated the need to increase the women's participation, while analyzing the power relations involved in decisionmaking processes regarding climate change and forests (Mai et al. 2011; Nelson and Stathers 2009).

On the other hand, while reducing atmospheric carbon emissions from tropical deforestation is at present considered the most cost-effective option for mitigating climate change, DeFries et al. (2010) pointed out that efforts should be focused on reducing deforestation for industrial-scale and export-oriented agricultural production. According to DeFries et al. (2010), the tropical forest loss in 41 countries between 2000 and 2005 positively correlates with urban population growth and exports of agricultural products at that time. Among those countries in humid tropical areas, Brazil and Indonesia together accounted for $41 \%$ of global tropical forest loss in this 5 -year period (FAO 2000, 2005), and the new agents of deforestation were found to be well-capitalized farmers and loggers producing for international consumers. In Indonesia, Rudel et al. (2009) identified the drivers of deforestation, particularly in the $21^{\text {th }}$ century, had changed from small-scale farming to industrial-scale, exportoriented agricultural production, such as oil palm (Elaeis guineensis) and rubber (Hevea braziliensis) monoculture. In the context of this paradigm shift in the drivers of deforestation as observed in Indonesia (van Noordwijk et al. 2012; Villamor et al. under review), Rudel et al. (2009) have suggested that strategies for conservation should be differentiated from the usual drivers of deforestation. This can be achieved by focusing on conservation of the uplands, and promoting environmental stewardship in the lowlands, which are more conducive to industrial agriculture.

However, to date, gender studies have not been concretely linked with these new developments. While there are ample studies demonstrating the disproportionate vulnerabilities to and impacts of climate change and related risks experienced by women, there is scarce empirical evidence showing how men and women, respectively, make decisions regarding new land use opportunities that enhance or reduce emissions (Behrman et al. 2012). Questions that remain insufficiently answered include: 1) How do males and females differ in terms of their land use perspective?; 2) What variables determine the land use decision making of males and females?; and 3) How do males and females differ in their responses to land use options in a social setting where competing agents are promoting either conversion or conservation? In this study, we address these questions using a multi-method approach. 


\subsection{Gender and land use analysis}

While the absence of women in natural resource management is perceived as an indicator of a project's failure (Agarwal 2001; Colfer 2012), women in the agricultural communities of Sumatra, Indonesia are rarely invited to participate in decision making at the village level. Men and women are ascribed different roles in agricultural activity, as regulated by local customary law or adat. For example, in several forest margin areas, women do most of the agricultural labor while men work in the forest.

Conversely, some communities in Sumatra practice a matrilineal kinship system, whereby land (particularly rice (Oryza sativa) fields) is bequeathed by a mother to her daughters or nieces (Martial et al. 2012); this is particularly the case in the Minangkabau and Jambi Melayu ethnic groups. Within this matrilineal system, women have strong land rights, life according to egalitarian ethics, and experience a relative absence of gender discrimination (Otsuka et al. 2001; Quisumbing 2001). Even in a bilateral system where the community embraces both matrilineal and patrilineal systems, women have more access and control over agricultural land than do men. For example, in the buffer zone area of Kerinci Seblat National Park, a matrilineal inheritance system was active in collective family ownership, particularly with regard to lowland paddy fields, while ownership of commercial tree crops, such as rubber, cinnamon (Cinnamomum burmannii), and coffee (Coffea robusta) were more individualized (owned by a single family) and is inherited by sons (Martial et al. 2012; Otsuka et al. 2001; Quisumbing 2001; Suyanto et al. 2001a, b; Villamor 2012).

However, the traditional matrilineal inheritance system has undergone substantial transformation (Otsuka et al. 2001; Quisumbing and Otsuka 2001), usually associated with the evolution of communal ownership towards individualized ownership (single family ownership). Accordingly, in upland rubber fields, the traditional matrilineal system has been replaced by a modified matrilineal system in which land is bequeathed within a nuclear family from father to son, as is also the case with upland cinnamon fields where individualized ownership is more common (Quisumbing and Otsuka 2001; Suyanto et al. 2001b). Thus, changes in the matrilineal inheritance system have affected gender relations in Sumatra by strengthening the land rights of men through planting trees as a way to privately claim communally controlled land (van Noordwijk et al. 1998), while eroding women's land rights (Quisumbing 2001). In this regard, it is imperative to analyze how both males and females respond to new land use options that subsequently affect their respective land rights.

Gender analysis uses a wide range of methods such as focus groups, wealth ranking, structured interviews (Feldstein and Jiggins 1994). However, in forestry research, the most commonly used approaches are on-site observations, focus group discussions, and interviews with key informants (Colfer and Minarchek 2012; Mai et al. 2011). Analysis of the decision making of different agents or actors in land use change also uses multiple methods and approaches. One conventional method is the use of ex-post statistical regression models to analyze the different factors affecting farmers' decisions to adopt or change farming practices, inferring motivation and preferences from correlates of alternative choices (Evans et al. 2006; Greiner and Gregg 2011).

In addition, role playing games (RPGs) have been used in many research studies to collect information about stakeholders' perceptions of the situation depicted in the modeled landscape, including decision-making rules and behaviors (Robinson et al. 2007; Smajgl et al. 2011; Villamor and van Noordwijk 2011). They have also been used to test scenarios, facilitate negotiation support and validate multi-agent simulation (MAS) models (Castella et al. 2005; D' Aquino et al. 2003; Villamor 2012). RPGs are also used to reveal facts that 
could not easily be communicated through a conventional means of data collection (Vieira Pak and Castillo Brieva 2010; Villamor and van Noordwijk 2011), and to demonstrate that individuals behave differently in a group setting. Based on the literature review conducted by Mai et al. (2011), RPGs combined with household surveys have never been employed in gender analysis in forestry research.

In this paper, we present a close-to-real-life simulation of forest-margin change by examining the decision making of females and males with respect to their land use in a more direct and explicit way. A land use RPG was carried out in combination with a household survey in order to elicit the gendered issues and other related factors that affect people's land use decisions, before moving on to the next step of interacting with the natural system through MAS models. Accordingly, we recognized that social systems are dynamic and complex, and that decision making processes can be better explored using a multi-method approach.

\section{Methodology}

\subsection{Study area}

The study was conducted in a rubber agroforest landscape in Jambi Province, in Sumatra, Indonesia. A total of six villages were selected across a stratification based on elevation (lowland and upland) and the degree of previous involvement in conservation boundary work undertaken by the World Agroforestry Centre (ICRAF) and its partners (Fig. 2). Three

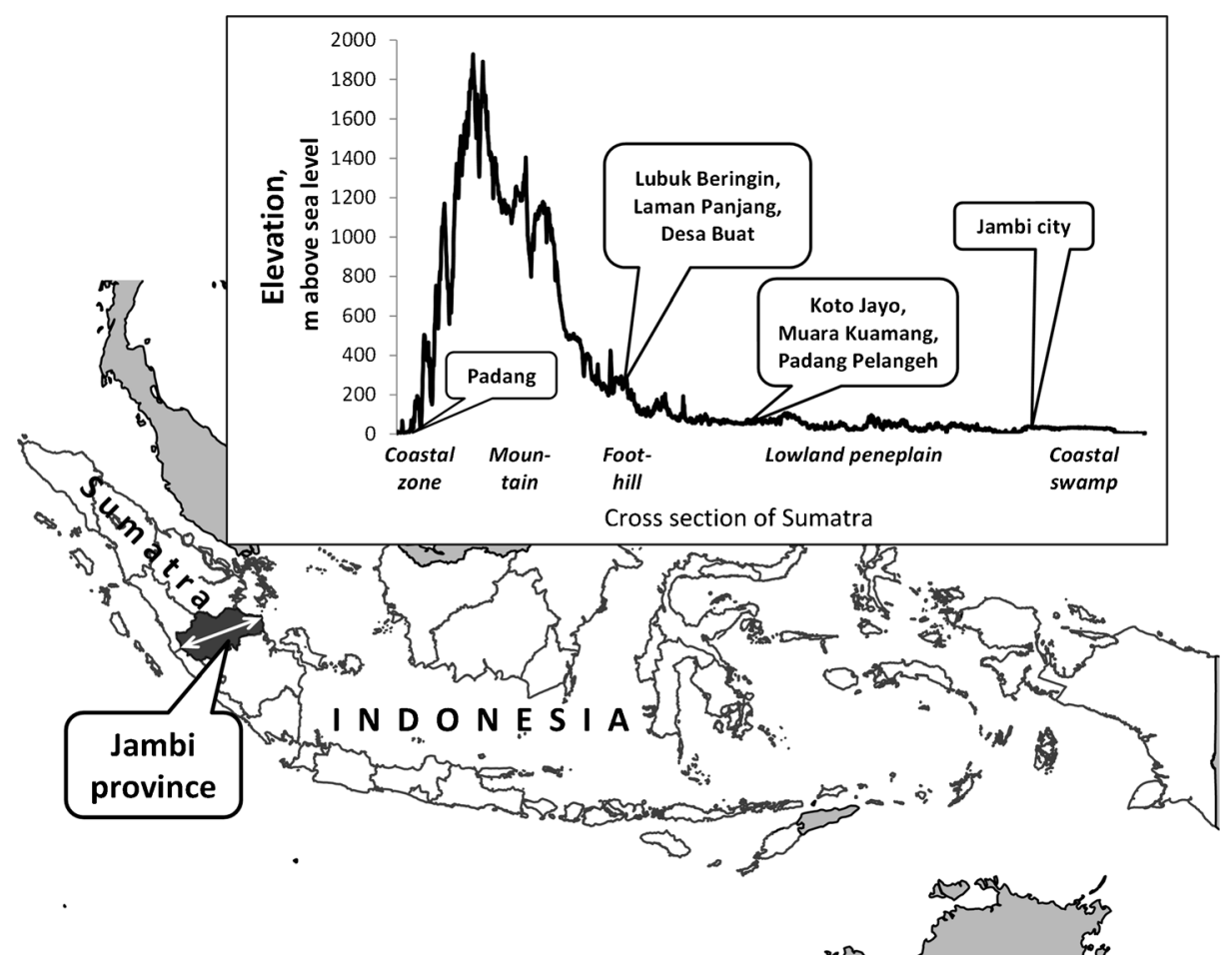

Fig. 2 The study area showing the elevation gradient in Jambi Province, Sumatra, Indonesia 
upland villages in the foothill zone (up to $1,300 \mathrm{~m}$ above sea level) of the Bukit Barisan mountain range and the buffer area of the Kerinci Seblat National Park were selected, as well as three lowland villages in the peneplain zone (110-150 $\mathrm{m}$ above sea level). The three villages in the upland area are Lubuk Beringin, Laman Panjang and Desa Buat. These three villages were selected on the basis of the existing rubber agroforests they maintained and their previous involvement with ICRAF. Lubuk Beringin and Laman Panjang have been involved in the Integrated Conservation and Development Projects (ICDP) since the early 1990s, which was taken over by the Rewarding Upland Poor for Environmental Services (RUPES) program in the late 2000s (Akiefnawati et al. 2010) to explore and establish rewards for environmental services from rubber agroforests, such as REDD + . According to Akiefnawati et al. (2010), the initial primary benefit from the pilot REDD+scheme to the community is the security of rights and opportunities to derive income from their agroforests and forests in their own way and style.

The three villages selected to represent the lowland areas were Koto Jayo, Muara Kuamang and Padang Pelangeh. These are the only villages left with substantial rubber agroforests since most of the lowland areas have been converted into oil palm and monoculture rubber plantations and have not been involved in any conservation projects.

The study area has been dominated by rubber agroforests for most of the $20^{\text {th }}$ century (van Noordwijk et al. 2012), although much of the land has been converted to monoculture rubber and oil palm plantations during the past two decades, starting with the lowland areas, as noted above. Mining activity has also started in the study area (particularly in the lowland area) over the past decade.

\subsection{Surveys}

Surveys were conducted in order to explore the socio-economic characteristics of individual farmers, as well as the factors influencing their decisions to change or maintain the existing land use. The sampling was designed to collect data in upland areas with high conservation intervention (given that this zone is considered a conservation priority) and lowland areas with very limited or almost no conservation intervention (as it is considered too late for action in most cases). While Villamor and van Noordwijk (2011) reported a difference in behavior between the results of the RPG and individual's responses to survey questions concerning the likelihood of land use change, we replicated this study using both survey and RPGs together to check for gender differences in the responses, and to cover a possible gap between the two types of information.

A total of 389 households were randomly selected within the six villages for the survey, of which 189 (49\%) were male respondents extensively interviewed between 2010 and 2011, while the remaining 200 (51\%) were female respondents interviewed from April to June 2012. The survey questionnaire covered the households' and farm characteristics, access to natural and financial capital, and land use preferences.

\subsection{Land use role-playing games (RPGs)}

Once the survey was finished at each village (sub-set), we immediately employed a land use RPG with the respondents of each sub-set to explore the respondents' responses to land use options in a social setting. We applied the exact land use RPG procedures described by Villamor and van Noordwijk (2011). A land use game board with a grid of $5 \mathrm{~cm} \times 5 \mathrm{~cm}$ blocks represents each village where the survey respondents live. In order to capture the actual land use types, the basic land use types of the game boards were varied according to 
village elevation (Fig. 3). For the upland villages, each game board consisted of a village, one unit of rice field (rain-fed rice), nine units of rubber agroforests and 14 units of forest, which represent the composition of the major land use types in the upland landscape. For the lowland villages, each game board consisted of a village, 10 units of monoculture rubber and 14 units of rubber agroforests representing the composition of the major land use types in the lowland landscape. Each land use type has a corresponding income value. Based on negotiations with other agents, income from either maintaining or changing the land use is assumed to be a feedback, in which the increase or decrease of income is an effect of changing or maintaining land use (Fig. 1).

\subsubsection{Players and roles}

Of the total 389 survey respondents, only 106 were willing to participate in the RPGs. A total of four RPGs were conducted, of which two games were women-only (one for upland villages and one for lowland villages) and another two games were played predominantly by men, with just 2-3 women participating (we suspected that they could be the daughters or wives of participants and were not that active during the game session). For each of the four games, the players were grouped according to their own villages, making three groups (or villages) per game. Through this arrangement, the players could better relate to each other, being more familiar with their own village conditions and co-villagers. The first set of male RPGs in the upland was carried out in 2010, then another set of male RPGs took place in 2011. The two women-only RPGs took place in 2012. The time that passed between the first two games allowed us to make necessary adjustments in the game design that would help us capture actors and land use compositions more appropriate for lowland conditions (see section 5.2).

The lowland game followed the same actor roles and descriptions developed in Villamor and van Noordwijk (2011) for the upland elevation, while additional actors were added appropriate to the new land use types existing in the lowland villages, including:

- Villagers - A minimum income of 1 rupiah per year per person (fictional currency value) has to be maintained for survival. If they want to live comfortably (for example, to send

a

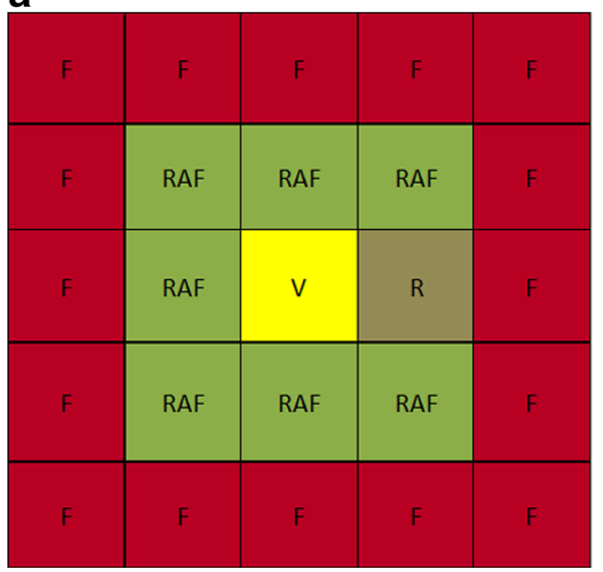

b

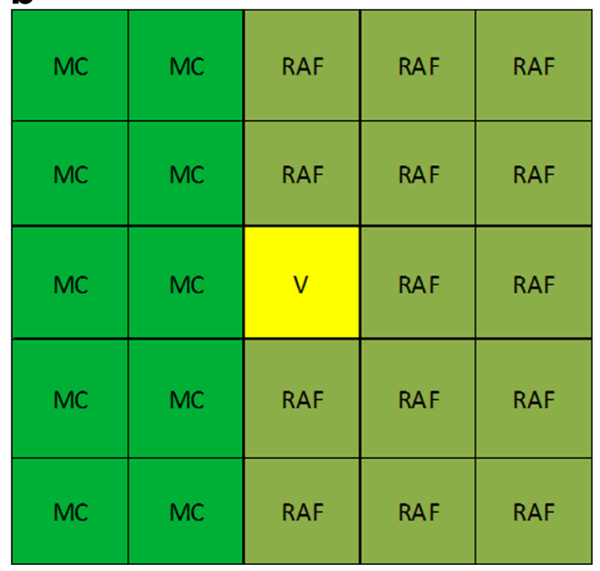

Fig. 3 Land use game boards for (a) upland village and (b) lowland village landscapes. Legend: $V$ village; $R$ rice; $R A F$ rubber agroforest; $F$ forest; $M C$ monoculture rubber 
their children to school), they need to increase their income. During the game, the villagers jointly decide on the land use and negotiate with the external agents.

- Logging company - A pulp and paper company wants to convert the natural forests for an attractive offer.

- Oil palm company - A company promises to convert any type of land to oil palm plantation for 8 rupiah per unit per year, but is still negotiable.

- Green rubber company - A company is seeking sustainable rubber production where villagers are signatories to a watershed protection program as well as biodiversity conservation. It awards an additional 2 rupiah per unit of rubber agroforest per year.

- Non-governmental organization (NGO) - For upland villagers, the NGO represents the "Save-the-Tiger" group, offering rewards to villagers with minimum units of continuous forests or rubber agroforests. For the lowland, the NGO represents the conservation of agro-biodiversity by maintaining a minimum number of continuous rubber agroforests.

- Government agriculture agency - For lowland villages, this local government unit offers financial support to promote monoculture rubber plantations of 5 rupiah per unit per year.

- Government watershed board - For upland villages, this local government unit offers recognition for conservation efforts by protecting the watershed.

- Coal mining company - A mining company is interested in converting any type of land into coal mining areas for 12 rupiah per unit per year.

\subsubsection{Game settings and sessions}

We followed the exact same game settings described in Villamor and van Noordwijk (2011), whereby the villagers cannot expand their rice fields and village area owing to the physical constraints of their land (terrain). The population at the initial year (start of the game) is 75 for the uplands and 100 for the lowlands. A score sheet is provided to monitor the income conditions of the players and how targets are met. Play money was used to represent financial benefits from negotiating with actors (for example, the oil palm company, logging concession company, watershed protection board, NGO, and green rubber company), and stickers were used to recognize the village conservation efforts.

After the roles and descriptions of the actors were voluntarily selected by the players, instructions were provided on how to play the game. A group of buyers received their instructions separately from the rest of the villagers. Indeed, not knowing the details of each other's role description beyond what agents disclosed in discussions was considered part of the game's design. Some roles were allowed to be conflicting and contradictory in order to encourage players to find innovative solutions within the RPG context. In every round, the buyers visited the villages and negotiated according to their respective targets, with each round of negotiation lasting around $15 \mathrm{~min}$.

The game master announced when the set time was over, and the buyers returned to their respective places to check their targets while the villagers calculated their income for the given year using the score sheet (Villamor and van Noordwijk 2011). Furthermore, exogenous changes (unexpected perturbations) were announced as scenarios or stressors in the game, thus complicating the players' attempts to meet their targets. A population increase of $20 \%$ was enforced in round 3 , due to a government transmigration program. In year 4 , three units of forest for the upland and three units of rubber agroforest in the lowland were burned down in a natural forest fire incident, and consequently no income was generated, and the rubber price decreased by $50 \%$ in year 5 . 


\subsection{Data analysis}

\subsubsection{Survey}

The data collected during the surveys was first used to characterize the sample respondents using Principal Component Analysis (PCA). PCA was run to condense information from a large number of original variables into new composite components with minimal loss of information. Variables with a Kaiser-Meyer-Olkin (KMO) of $>0.60$ were included as a measure of sampling adequacy, and those variables with higher loadings per identified component were selected.

Then, binary logistic (bi-logit) regression analysis was used to identify the determinants of each respondent's decision to change or maintain the current land use. This regression analysis is based on the maximization of an underlying utility function that is assumed to be consistent with individual household behavior (Zbinden and Lee 2005). The model characterizing willingness to change land use is specified as:

$$
\log \left(\frac{P_{i}}{1-P_{i}}\right)=\beta_{0}+\beta_{1} x_{i}+\beta_{2} X_{2}+\ldots+\beta_{k} X_{k i}
$$

where: $i$ denotes the $i$-th observation in the sample, $P_{i}$ is the predicted probability of changing land use, which is coded with 1 (change the land use) or 0 (not to change or maintain), $\beta_{i}$ is the intercept term, and $\beta_{1}, \beta_{2}, \ldots, \beta_{k}$ are the coefficients associated with each explanatory variable $X_{1}, X_{2}, \ldots X_{k}$.

For explanatory variables, the procedures devised by Rothman (2012, p. 223) to include the relevant confounders in the model were followed, and a set of outcome predictors, based on the strength of relationship to the outcome, were subsequently identified. The relationship is identified by quantifying the amount of change in the coefficient of the variable of interest (i.e. gender) after each predictor variable is introduced in succession. If the coefficient of the variable of interest changes considerably (namely a change of greater than $10 \%$ ), the predictor variable is added to the model as a confounder. This procedure helped identified five essential confounders or explanatory variables (two for the lowlands and three for the uplands) for the effect of gender in a household's decision to change or maintain their current land use. The following are the relevant confounders, with supporting literature:

1. Number of mobile phones: while mobile phones represent a medium for effective agricultural extension services, existing literature highlights a relative difference between men's and women's access and use. For example, there is a strong gender divide in access in India and Pakistan, yet no significant difference in the Philippines and Thailand, where mobile phones are more prevalent (Zainudeen et al. 2010). In terms of mobile phone use, men typically use mobile phones as a symbol of social status, while women use them as instrument of expression and sociability (Plant 2001).

2. Total land size: Coomes and Burt (1997) show that the total area of household land holdings represents the most powerful predictor in the regression model of inter-field diversification.

3. Age: generational age has been found to significantly influence farmers' choices. Younger farmers tend to be more explorative, while older farmers tend to keep to their old ways (Vanslembrouck et al. 2002; Wossink and van Wenum 2003).

4. Dependency ratio: in Sumatra, most farming systems depend on household or family labor, and the dependency ratio relates to the availability of labor (people of working age: from 15-60 years old). According to Suyanto et al. (2001b), when the revenue of a 
family is low, more family labor is used. Thus, when a household has many members above the age of 15 years old, more labor is available, and the household is more likely to choose more labor intensive farming practices.

5. Income from rice: many studies have used this factor as a respondent characteristic when assessing the adoption of agroforestry practices and conservation activities, although the effect on the respondents' decision making have been variously found to be both positive (Le 2005; Neef 2010; Vanslembrouck et al. 2002) and negative (Villamor 2012; Wossink and van Wenum 2003).

STATA 12 software was used for the statistical analysis, with the results presented in terms of an odds ratio as a measure of association between a variable of interest and the outcome. The odds ratio is the exponential function of the regression coefficient associated with a one-unit increase in the variable of interest (Szumilas 2010). Using bi-logit regression, the explanatory variables are automatically adjusted.

\subsubsection{RPG}

A score sheet was provided for recording income and units of land use changes to track the changes of land use types in the RPG game board. The data from the score sheets was subsequently analyzed using Excel spreadsheets, and translated into graphic form to observe the pattern of land use change. Based on the land use negotiated with other agents, income was calculated as a direct benefit of a player's decision. A video recorder was used to document the discussions and negotiations of the whole game; it also provided a means of triangulation.

\section{Results}

\subsection{Socioeconomic characteristics}

Descriptive statistics with the key variables that differentiate respondents from the lowland and upland areas are summarized in Table 1. These key variables can be grouped according to respondents' and farms' characteristics and access to communication and their means of mobility. The respondents from the lowland area have better mobility and access to communication infrastructure compared to those from the upland area. Only the upland respondents have rice fields (with an average of $0.8 \mathrm{ha}$ ), while only lowland respondents have oil palm plantations (with an average of $0.6 \mathrm{ha}$ ). On the other hand, the upland respondents have almost 2 ha more of the average total landholdings than the lowland respondents. In terms of average annual gross income, the lowland respondents earned 1,000 USD more per year than the respondents from the upland area. However, it was beyond the scope of this study to include the value of other forest products (such as fiber, honey, timber and medicinal plants) that the respondents from the upland usually collect in the neighboring forests for their household consumption.

\subsection{Determinants of individual land use change decisions}

\subsubsection{Lowlands}

The variables affecting decisions to change or maintain land use are summarized in Figs. 4 and 5. The five variables significantly associated with the decision of the lowland 
Table 1 Descriptive statistics of the respondents in Jambi Province (Sumatra), Indonesia (2010-2012)

\begin{tabular}{|c|c|c|c|c|c|c|}
\hline Key variables & Elevation & $\mathrm{N}$ & Mean & $\begin{array}{l}\text { Standard } \\
\text { deviation }\end{array}$ & Min & Max \\
\hline \multirow[t]{2}{*}{ Age } & Lowland & 194 & 43 & 11.1 & 23 & 82 \\
\hline & Upland & 195 & 39 & 11.8 & 19 & 75 \\
\hline \multirow[t]{2}{*}{ Size of household (\#) } & Lowland & 194 & 4.1 & 1.2 & 2 & 8 \\
\hline & Upland & 195 & 4.6 & 1.4 & 2 & 9 \\
\hline \multirow[t]{2}{*}{ Motorcycle (\#) } & Lowland & 194 & 1.5 & 0.8 & 0 & 4 \\
\hline & Upland & 195 & 0.9 & 0.6 & 0 & 4 \\
\hline \multirow[t]{2}{*}{ Mobile phones (\#) } & Lowland & 194 & 1.7 & 1.2 & 0 & 6 \\
\hline & Upland & 195 & 0.1 & 0.4 & 0 & 2 \\
\hline \multirow[t]{2}{*}{ Rubber agroforest (ha) } & Lowland & 194 & 3.0 & 3.1 & 0 & 26 \\
\hline & Upland & 195 & 4.1 & 4.9 & 0 & 45 \\
\hline \multirow[t]{2}{*}{ Rice field (ha) } & Lowland & 194 & 0 & 0 & 0 & 0 \\
\hline & Upland & 195 & 0.8 & 0.7 & 0 & 3.5 \\
\hline \multirow[t]{2}{*}{ Monoculture rubber (ha) } & Lowland & 194 & 0.3 & 0.8 & 0 & 6 \\
\hline & Upland & 195 & 0.1 & 0.3 & 0 & 3 \\
\hline \multirow[t]{2}{*}{ Oil palm plantation (ha) } & Lowland & 194 & 0.6 & 1.1 & 0 & 6.5 \\
\hline & Upland & 195 & 0 & 0 & 0 & 0 \\
\hline \multirow[t]{2}{*}{ Gross income (USD/yr) } & Lowland & 194 & 5,731 & 3,978 & 1,066 & 24,588 \\
\hline & Upland & 195 & 4,303 & 5,088 & 156 & 41,582 \\
\hline \multirow[t]{2}{*}{ Total land holdings (ha) } & Lowland & 195 & 4.04 & 3.7 & 0 & 27 \\
\hline & Upland & 195 & 5.91 & 6.4 & 0 & 64 \\
\hline
\end{tabular}

Key variables were derived from PCA using Varimax with Kaiser Normalization

respondents to change land use area are gender (female) $(p<0.05 ; \mathrm{p}$ is probability of this variable or stronger result under null-hypothesis of no influence), total land size $(p<0.01)$, total area of oil palm plantation $(p<0.05)$, income per capita $(p<0.05)$ and total area of rubber agroforest $(p<0.05)$. It shows that the odds of a female changing land use were $60 \%$ lower than for a male (Fig. 4). The odds of changing increased by $30 \%$ per additional 1 ha of respondent's land size, while the odds of changing decreased by $44 \%$ and $32 \%$ per additional 1 ha of respondents of oil palm plantation and rubber agroforest. Furthermore, the odds of changing decreased by $42 \%$ per 1,000 USD income per capita of the respondent. In terms of non-significant, yet potentially relevant variables, the odds of changing increased by $88 \%$ per 1 unit of mobile phone ownership.

Among these variables, the total land size and income per capita were assessed to have the highest impact (measured in coefficients size of standardized variables). Consequently, the probability of changing land use for a male is $33 \%$ and the average probability of changing land use for a female is $17 \%$.

\subsubsection{Uplands}

The two variables most significantly associated with the decisions of the upland respondents to change land use are age $(p<0.01)$ and \% income from rice $(p<0.01)$, while other variables include gender (Female, $p<0.06)$, household size $(p<0.07)$ and group membership $(p<0.06)$ (Fig. 5). The results show that the odds of changing decreased by $8 \%$ per 1 year of the 


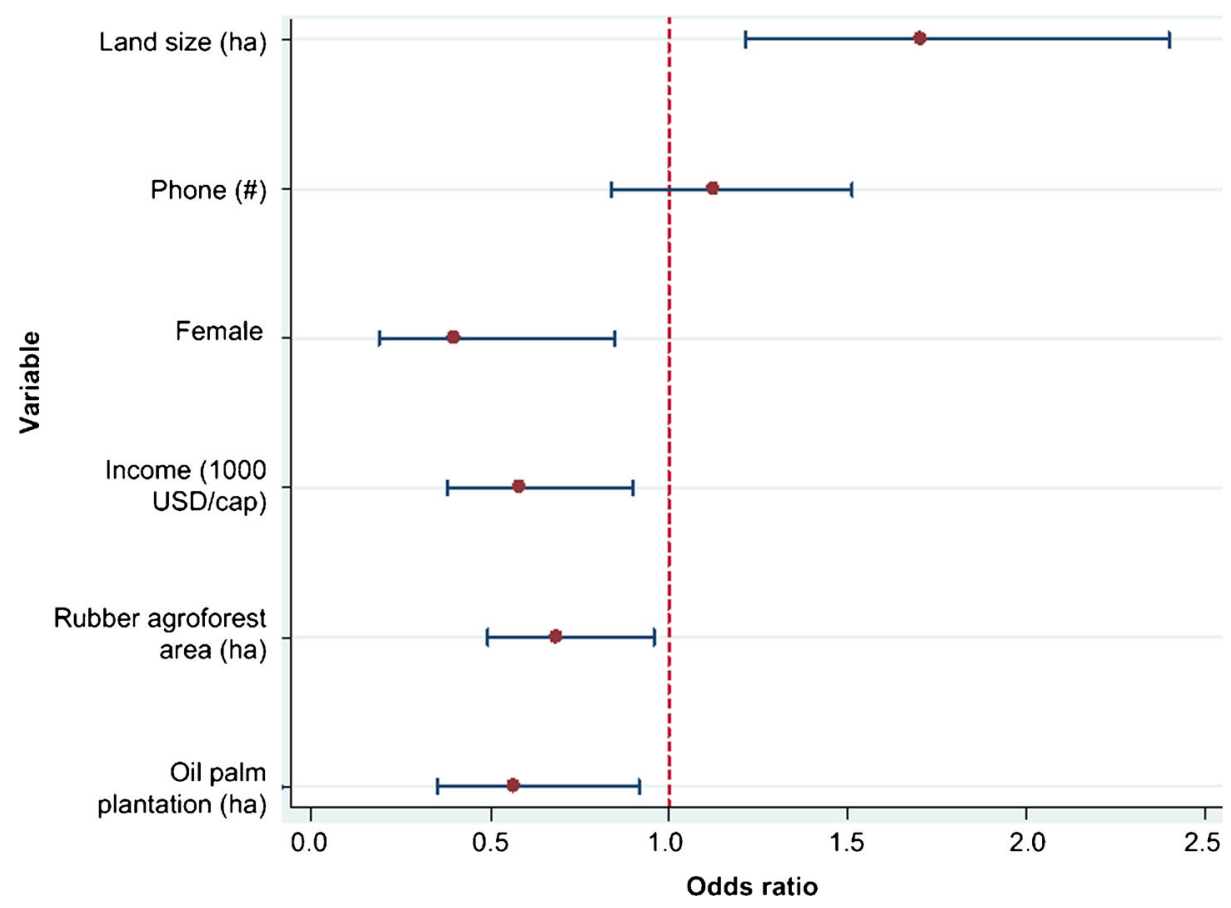

Fig. 4 Odds ratio of the variables in a binary logistic regression model of willingness to change or maintain land use in the lowland area $\left(R^{2}=0.12 ; p<0.0006 ; N=194\right)$

respondent's age, while the odds of changing decreased by at least $2 \%$ per one percentage point increase of rice share on income. On the other hand, the odds of a female changing are $63 \%$ lower than for a male. The odds of changing decreased by $23 \%$ per additional member of the household, and by $41 \%$ per additional group that the respondent participated in.

In terms of non-significant yet potential relevant variables, the odds of changing increased by at least $21 \%$, but not more than fourfold of the odds of changing, if people do not participate in Conservation Agreements (CA). The odds of changing by $44 \%$ per unit increase if there are dependents, while the odds of changing increased by $76 \%$ per additional member of a household. In terms of income, the odds of changing decreased by $4 \%$ per 1,000 USD gross annual income of the respondent.

The variables with the highest impact in the decision to change were age and income from rice. Consequently, the average probability of changing land use for males is $70 \%$ and $51 \%$ for females.

\subsection{Perceived land use change in a group setting}

\subsubsection{Lowlands}

The perceived land use change pattern (as an emergent property) resulting from the participation of lowland respondents playing RPGs according to gender, and in which external agents offered various land use options, are portrayed in Fig. 6. Both male and female decision makers accepted offers from the oil palm company as soon as their villages were approached. All the female dominated landscapes featured an increasing trend towards 


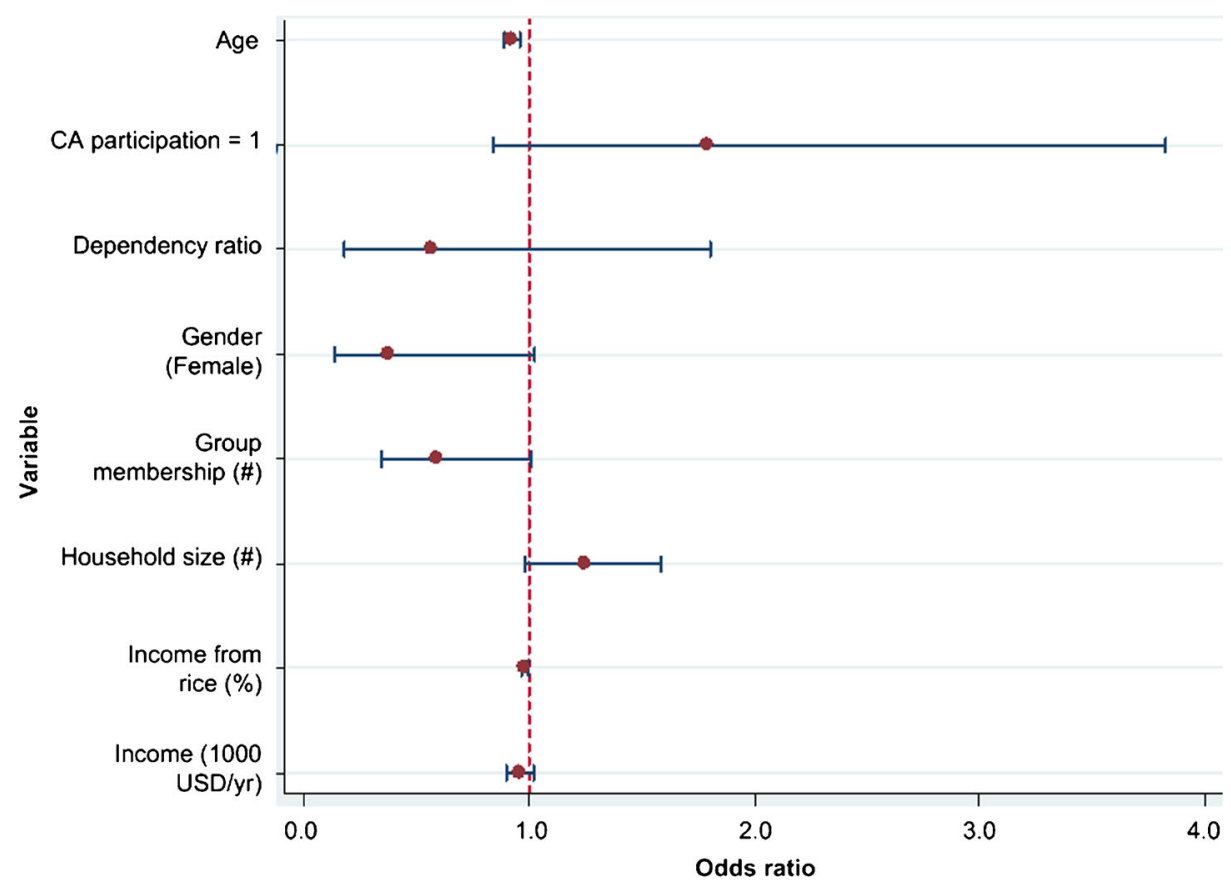

Fig. 5 Odds ratio of variables in a binary logistic regression model of willingness to change or maintain land use in the upland area $\left(R^{2}=0.10 ; p<0.0006 ; N=195\right)$

coal mining, while two of the three male dominated villages already had coal mining agreements (Fig. 6b). Both female and male decision making landscapes showed a decreasing trend in rubber agroforests in favor of oil palm and coal mining.

\subsubsection{Uplands}

For the upland respondents, the apparent land use change pattern in the female-only RPGs (Fig. 7a) appeared after year three in contrast with that in the male-only RPGs (Fig. 7b). While oil palm and logged forest areas emerged in the landscapes where the women took decisions, the men rejected offers from the oil palm and logging companies. Despite both groups showing a decreasing pattern of forest area due to natural forest fires, landscapes influenced by female decision making showed increased rubber agroforest areas.

Males from the upland areas did not opt to change to more profitable land uses, but rather negotiated and made contracts (using stickers) with the conservation agents (such as 'Savethe-Tiger' NGO, green rubber company and watershed protection board). Despite the profit being low compared to the offers from the oil palm and logging companies, these contracts allowed people to maintain the landscapes. If we were to allocate conservation points (such as increase in agro-biodiversity) for maintaining such land uses, then the males would have had more intangible conservation points than monetary benefits. On the other hand, the women retained almost the same number of rubber agroforest units during the whole game, except only deciding to change after exogenous stressors were announced, with the clear intent of meeting their income targets. The two female-only groups also made the interesting 
a

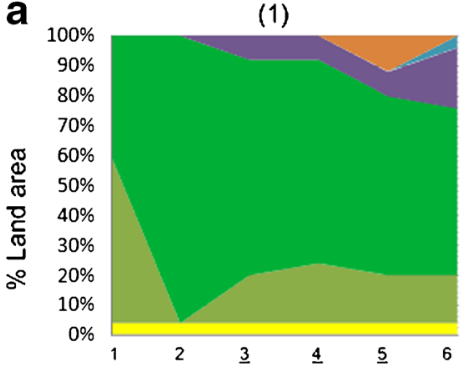

b

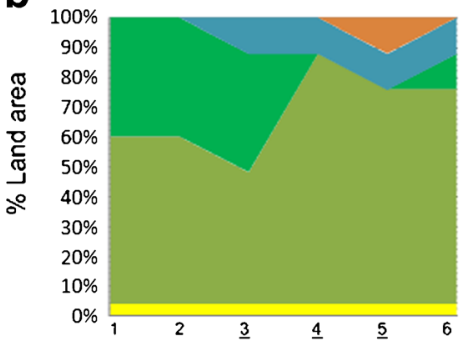

Legend:
(2)
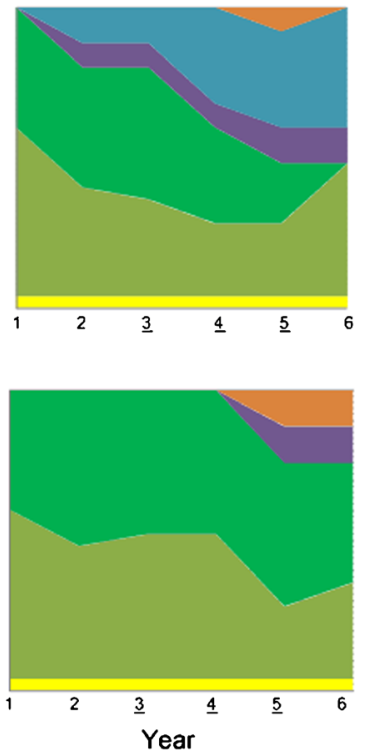

Monoculture rubber - Oil Palm
(3)
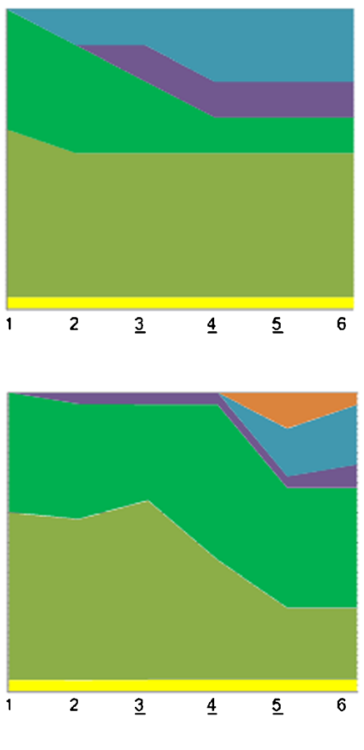

Rubber agroforest

Settlement

Fig. 6 Perceived land use pattern between females (a) and males (b) in the lowland villages: Koto Jayo (1), Muara Kuamang (2), and Padang Pelangeh (3). Underlined years show that a stressor was implemented

decision to convert the burnt areas into an oil palm plantation (Fig. 7a.2 and a.3), something that did not occur during the male-only RPG (see section 4.3 for further discussion).

\subsection{Income differentiation}

The majority of the females in both upland and lowland villages outperformed their male counterparts in achieving their income targets (Fig. 8). The majority of the males in the upland villages (Fig. 8b) showed similar patterns of income generation; they tended to maintain their land uses during the course of the game and did not accept any offers from external agents. Consequently, when under stress (such as population increase, forest fire or decrease in a rubber price), their income was below target. Despite this relatively low income, they were awarded for the conservation efforts they had negotiated with the external agents. In contrast, all the females accepted offers from external agents when under stress. Only the females and males from the village of Laman Panjang showed a comparable income trend (Fig. 8a, b).

For the lowland villages, the females' incomes also exceeded the target, even when under stress (Fig. 8c), while almost all males reported comparable income patterns as males from the uplands (Fig. 8d). However, the income generated by males from the uplands was much lower than that of lowland males, due to the different dominant land uses and corresponding lower income values in their respective areas (Table 1). Accordingly, when no stressors were involved, the income generated by the lowland males was much higher (Fig. 8b, d). 
a

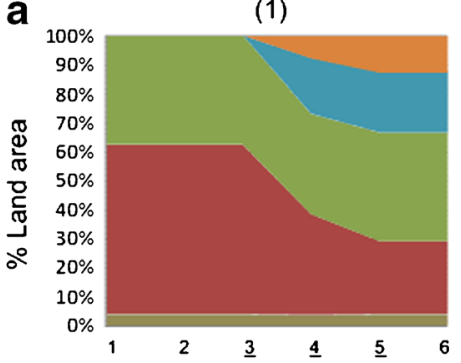

b

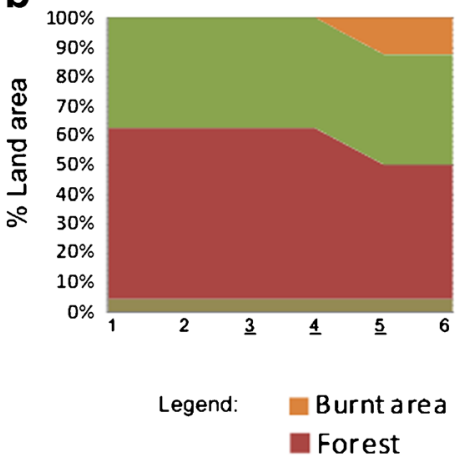

(2)
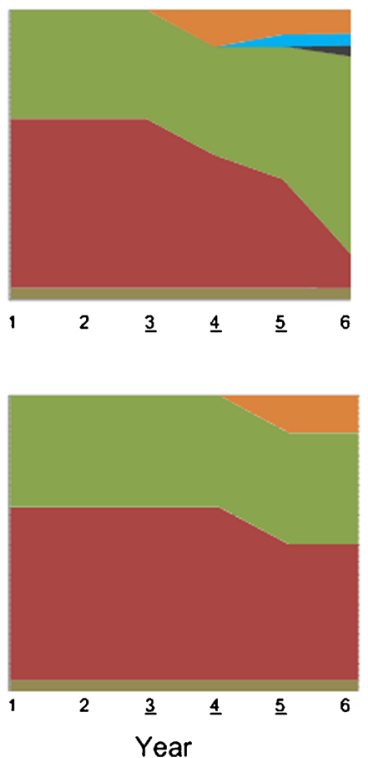

- Logged forest - Oil Palm
(3)
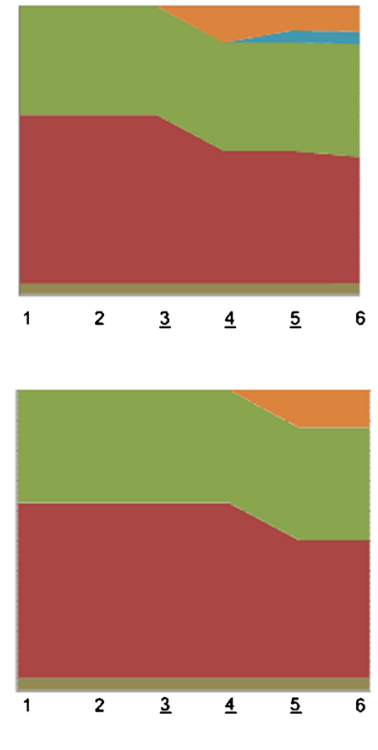

Rice land

Rubber agroforest

Fig. 7 Perceived land use pattern between females (a) and males (b) in the upland villages: Desa Buat (1), Laman Panjang (2), and Lubuk Beringin (3). Underlined years show that a stressor was implemented in each year

\section{Discussion}

4.1 What determines the land use decision making of males and females, respectively?

In both the lowland and upland areas, a clear difference was observed between male and female styles of decision making, particularly in terms of the significant and relevant factors associated with the decision to change current land use. The research showed that gender was a significant variable in the lowlands at the individual level, where the odds of females to change land use were lower than the males. That said, the number of mobile phones owned by respondents has been identified as a relevant confounder.

The association of these two factors is interesting, though it could not be studied comparatively in the uplands where there is not yet a functioning mobile phone network. However, this will change over the course of time. The study shows that, on average, women owned a higher average number of mobile phones than men in the lowland area. This contrasts with the observation made by IFPRI (2012) that men are more likely to own or have access to phones than women in rural areas. It is clear that access to mobile phones represents a means of communicating and sharing information. In the lowland context, this is possibly a contributing factor to women's competitive performance in achieving income targets during the games. It is also possible to consider the use of mobile phones in association with decision making as a means of empowering women in land use decision making in areas where rice fields (as an indicator that a matrilineal system is operating) have already been converted to other land uses.

Despite rice being the staple food for people of both the upland and lowland areas, there is an interesting link between age, gender and rice production - particularly in the upland 


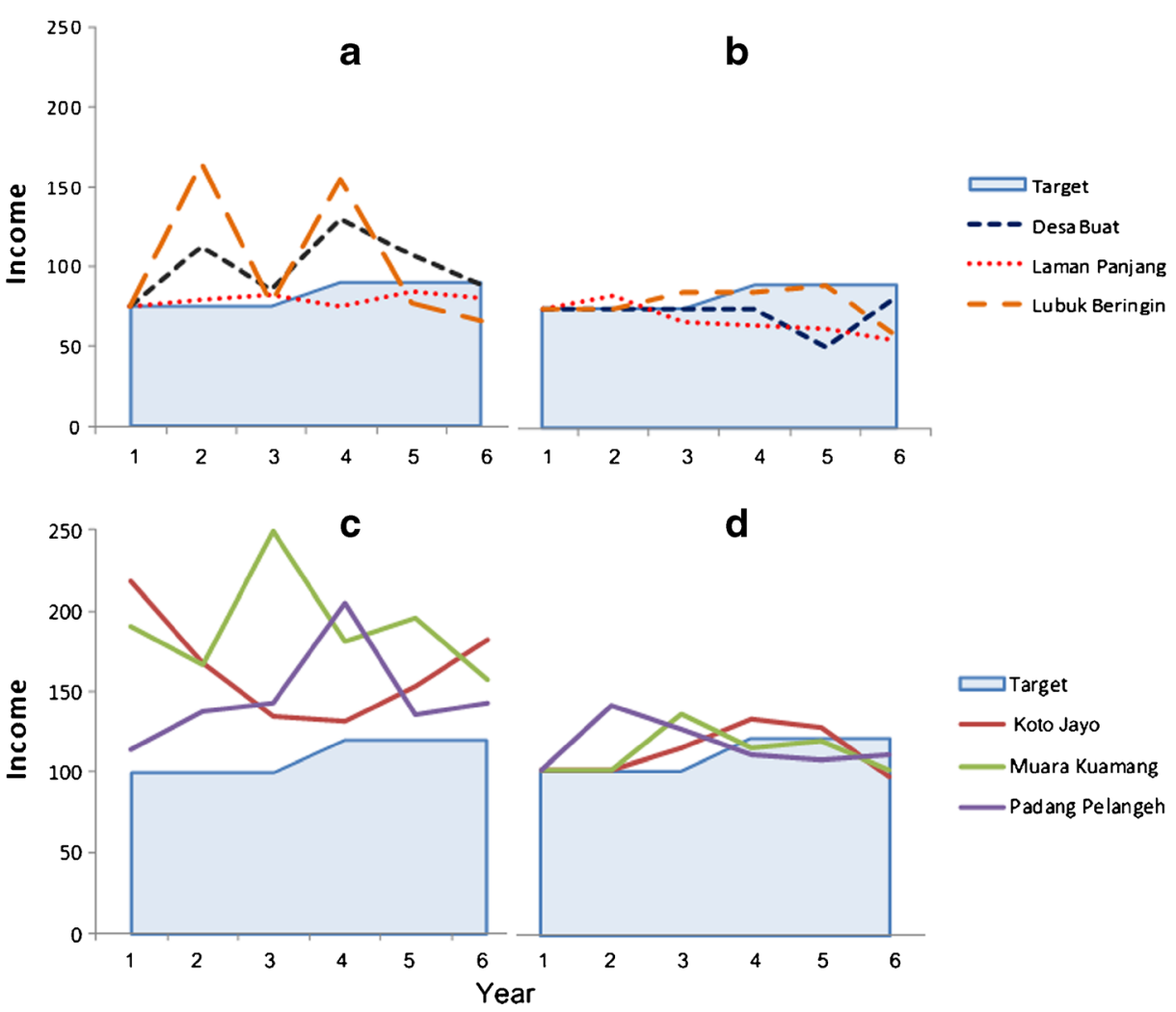

Fig. 8 Income differentiation between females (a) and males (b) in the upland villages and between females (c) and males (d) in the lowland villages

areas, where traditional rice production is still practiced and the harvest is mainly used for household consumption. According to Fig. 5, the share of rice in the household income is strongly associated with land use decisions. The higher the percentage contribution of rice to household consumption, the higher the likelihood that a respondent will not change their land use. Furthermore, it suggests that the respondents pay serious attention to household consumption before considering the option of other land use practices. In the upland areas, the matrilineal system of land inheritance remains quite strong in comparison with the lowlands, where most rice fields have been converted to either oil palm plantations or monoculture rubber. The decision to change land use, particularly the rice component, will often fall to an elder female. However, if a female inherited a rice field at a young age, there is a high probability of changing the land use.

4.2 How do males and females differ in their perspectives on land use?

Contrary to expectations, the study showed that new land use types emerged more rapidly in the female- rather than male-managed land use game boards, particularly during simulated ecological and economic shocks or stressors (forest fires, population increase or commodity price fluctuations, for example). These changes affected mostly the forest areas in the upland villages, and the rubber agroforests in the lowlands. 
In the upland area with female landscape management, forests were converted to expand the rubber agroforest area. During the RPG, it was observed that females perceived rubber agroforest as economically superior to natural forest as these simultaneously offer both conservation and financial benefits. From their perspective, there was no environmental or income risk in changing forest into rubber agroforest, at least within the context of the game. By contrast, males in the upland area did not touch the natural forest in the same game. This perspective is possibly shaped by the value of the timber that the males in the upland collect from these forests, along with their strong conservation belief system, which is attributed to their long experience with various conservation and research organizations (Villamor and van Noordwijk 2011).

Females from the lowland area shared the same strategy of rapid land use change, having accepted the offers of highly profitable land uses, such as coal mining and oil palm plantations, at the expense of rubber agroforest. In contrast to their counterparts from upland villages, males from the lowland area negotiated with external agents to change their land use to oil palm, monoculture rubber and coal mining. Land use change was therefore observed on their game boards, with a decrease in rubber agroforest.

This pattern of land use change in the lowland areas was consistent with the land cover change assessments produced by Ekadinata and Vincent (2011) and Villamor et al. (under review) in the district and sub-district level of Jambi Province, which showed that rubber agroforests in the lowland areas were increasingly being replaced with more intensive farming options such as oil palm plantations.

\subsubsection{Does this suggest that females are better profit optimizers than males?}

Figure 8 shows that females in both areas performed very well in achieving their income targets within the RPG context. Interesting negotiations were made by women to increase their income, for instance, by securing much higher bids for their land use changes than did men in comparable circumstances.

The research findings concur with Coates (2012), who noted that men and women differ in performance in terms of trading and taking risks, with studies in real investment behavior demonstrating how women outperformed men over the long term. Indeed, in terms of formal finance theory, Coates suggests that women's high performance in this sphere is a sign of greater risk-taking. For example, Barber and Odean (2001, p.262) analyzed the brokerage record of 35,000 personal investors over the period 1991-1997 and found that single women outperformed single men by $1.4 \%$.

Although it is not clear whether risk-taking behavior plays an important role in women's attainment of higher incomes in this particular study, during the game it was observed that females are good traders. They negotiated much higher bids for changing their land use in comparison to their male counterparts: often two or three times the prices set in the game (see section 2.3.1).

On the other hand, the men, particularly in the village of Koto Jayo, found that they could use the double subsidy from the NGO and Government Agricultural Agency for conserving their rubber agroforest plots. Accordingly, they maintained and added more rubber agroforest plots right until the end of the game (Fig. 6a.1). Moreover, most of the male groups in the lowlands were quite reluctant to deal with the coal mining agent. They described how they have already witnessed the reality of how coal mining activities have failed to produce the long term wealth promised to their peers in neighboring villages, bringing environmental degradation instead. 
4.3 In a social setting, how do males and females respond to differing land use options with competing agents, promoting conversion and conservation?

It was relatively easy for both female and male players from the lowland areas to negotiate and convert units of rubber agroforest and monoculture rubber to oil palm plantation during the game. This RPG observation reflects the existing situation of oil palm and monoculture plantations in the lowland areas (Table 1), which have grown due to the good road access to markets (Miyamoto 2007). In fact, even before the stressors were implemented, most respondents accepted the offers of the external agents promoting conversion to rubber agroforests. It therefore makes sense to differentiate the analysis according to elevation gradients.

Female players from the lowland and upland areas were more responsive to external agent, particularly the oil palm company, than their male counterparts during the game. As noted, the bids made by female players to external agents were much higher than either the prices set in the game or bids made by male players. In fact, the majority of female players immediately converted their burnt areas to coal mining or oil palm plantations with much higher profits (Fig. 6); this was not observed in the male-only RPGs. This suggests that when there is an opportunity (in this case, a natural forest fire) there is a tendency for female players to maximize their land to seek more profitable options. Although the use of fire as a land clearing technique has been common in this area, it is now officially discouraged.

In comparison with the behavioral experiments conducted by Eckel et al. (2008) using simple two-player games (the dictator game and ultimatum game) to examine gender differences in negotiation situations, two key observations are consistent with our results: (1) women tend to be more egalitarian and more responsive to the context of the negotiation than men, and (2) women are more likely to accept an offer. However, the context of a laboratory experiment is much simpler than that of real world negotiations.

In the RPGs, the rejection of the oil palm and logging companies by the (particularly upland) male players could be attributed to the longstanding interventions of external agents promoting conservation. In reality, the villages selected in the upland area have been involved in various conservation and research activities with international and local agencies since 1998 (Akiefnawati et al. 2010). For instance, Lubuk Beringin village is the recipient of the first Hutan Desa or village forest agreement in Indonesia, a government strategy aimed partially towards reducing emissions from deforestation and degradation. They are therefore very aware of the potential consequences of converting natural forests and rubber agroforests into oil palm plantations. The survey results attested that the upland respondents did not own any oil palm plantations (Table 1 ).

Rubber agroforests are providers of local fruit and medicine, approximately on a par with the natural forests accessed by the villagers. However, the study did not show any particular gender differentiation in decisions to expand and maintain rubber agroforests in the upland RPGs. Overall, the men and women involved in the RPGs were equally attentive to the subsistence component of local livelihoods. While Villamor and van Noordwijk (2011) found that the male decisions in the social context of the RPG differed from the opinions expressed in individual interviews, the contrast seems to be even greater among females (from both the lowland and uplands). Moreover, there are many determinants (including unknown confounders that may interact with other factors are not captured using surveys) that can influence the decision to either change or maintain existing land use. However, in a group setting (RPG) where co-villagers are playing with each other, the players may fail to exchange all information they have and focus only on shared information to achieve their respective group goals (Moreland and Levine 2002). Individual players may change or 
suppress their behavior or choices due to peer pressure, the influence of dominant group members, and other group dynamics. Thus, it makes sense to represent the results of the land use RPG (which are simulated land use change patterns) as an emergent property of the interactions of the respondents who played during the games, integrating each individual's own socio-economic and cultural characteristics (Fig. 1). The principles of emergence imply that properties of the larger system (in this case, the respondents in a group setting playing RPG) may not resemble nor be intended by any of the constituent actors (methodological individualism). Rather, the societal (and ecological) patterns emerge from purposive choices and not from social facts external to individuals (Macy and Willer 2002).

\section{Policy implications and lessons learned}

\subsection{Gendered perceptions}

Respondents from both the lowland and upland areas, and particularly the women, indicated that there was likely to be a change in their land use patterns: from forest to rubber agroforest and oil palm plantation in the upland areas, and from rubber agroforest to monoculture rubber, oil palm plantation and coal mining in the lowland areas. Both these pathways could lead to substantial carbon losses. While absence of women in natural resource management is usually considered to be a failure, the RPG results suggest that the stronger involvement of women in decision making could potentially further increase the chances of land conversion, because of the female tendency to accept offers of conversion to oil palm and monoculture rubber plantations.

Conversely, we can learn positive lessons from the male players from the uplands. Given their long experience and involvement with international and local conservation agencies, there was clear evidence that enhancing the human capital behind conservation can have a long term effect in maintaining the natural forests and rubber agroforests in Sumatra, which in turn could reduce carbon emissions. Thus, investing in information dissemination activities concerning the value of ecosystem services provided by natural forest and rubber agroforests (including high carbon ecosystems such as peat swamps), and directly involving more women in these activities, would be worthwhile for both local and international conservation agencies involved in REDD+.

While developments in REDD+negotiation are currently progressing slowly, conservation agencies should also take the opportunity to develop and enhance women's established skills as entrepreneurs and traders of goods and services from forests and rubber agroforests. Eco-certification of latex from rubber agroforests is one option that should be further explored, especially in upland areas. The recommendation to vary conservation strategies according to upland and lowland locations (Rudel et al. 2009) is very relevant to the Sumatran context, as it has been shown that households respond differently according to elevation gradient of their location.

More importantly, although we do not have a full understanding of how the traditional matrilineal system developed in Sumatra (and in other places of the world), there is increasing evidence that the traditional system is transforming and affecting gender relations in lowland areas. It is therefore vital to study how matrilineal systems are changing in the face of agricultural industrialization, particularly given the pattern emerging in current research that suggests that women are more sensitive to the context of negotiation while men appear to be more responsive to pecuniary costs and benefits (Behrman et al. 2012; Eckel et al. 2008). 


\subsection{Tools and methods}

- The time gaps that occurred between subsets for the surveys and RPGs could be a source of bias. However, it was felt that the lapse affecting land use change in the uplands would be of little relevance to our study, as attested by the land use intensity analysis and validation (Villamor et al. under review).

- There are advantages to combining the survey with the land use RPG as a complementary approach to determining individual decisions and visualizing possible land use changes decided through group interaction, and analyzed according to gender, elevation and degree of conservation awareness. However, the development (and subsequent adjustments) of an RPG requires time and effort as it is essential that the design is appropriate to the situation in the local area. It must also be easily accessed and understood by the respondents.

- A survey alone could not provide clear gender differentiation in land use change patterns. Instead, the land use RPG explored emergent properties resulting from interactions between players and external agents with different objectives (such as promoting conservation or conversion). It is therefore a more dynamic approach.

- To better understand the potential social and ecological tradeoffs from the known factors affecting land use change, agent-based models are recommended (Villamor 2012; Villamor et al. 2011), based on known values and social learning styles.

\section{Conclusions}

A multi-method approach (with the survey and male-only and female-only RPGs) facilitates the examination of the determinants underlying individual behavior during land use change decision making (in response to external agents) in a group setting. The study showed that land use change outcomes vary according to (1) gender, in terms of response to external agents promoting either conservation or conversion, and in achieving income targets; (2) determinants or factors that influence land use decisions at the individual level, and responses to external agents in group settings, (3) elevation gradient, because the land use types in transition are mostly conversion from forests in the uplands, and from rubber agroforests in lowlands; and (4) the degree of conservation awareness intervention in terms of villagers' experience with external conservation agents. All of these factors will in turn affect the reduction and enhancement of carbon emissions within the area.

Women both from the upland and lowland villages who played the RPGs approached land use change in a more dynamic way than men from the same villages, reacting more positively to external investors proposing logging or oil palm conversion. Contrary to expectations and gender stereotypes, the increased involvement of women in landscape level decision making may serve to increase emissions from deforestation and forest degradation in the area, thus posing further challenges to emission reduction efforts.

These results will not resolve the longstanding call for the standardization of REDD+ guidelines and protocol, and seem instead to further complicate the negotiation process. As such, it is recommended that practitioners acknowledge the various drivers of deforestation and diversify options for conservation, rather than placing all the onus on a single scheme, such as REDD+. However, in the context of REDD + , it is suggested that more explicit attention is paid to the differential response between men and women to drivers of both deforestation and conservation. 
The stereotype of conservative and conservation-oriented females and more aggressively market-oriented males did not hold true in this case study, and a gender-balanced approach is needed for any government program that aims to modify land use decisions. Environmental protection cannot be expected to thrive unless both men and women see it as a net benefit. With greater empowerment of women in local decision making, a nonlinear 'Kuznetz curve' response can occur, whereby environmental quality may decline before awareness of what is being lost triggers a corrective movement towards conservation goals (Stern 2004). Policy support for greater gender equality in decision making does not necessarily and immediately coincide with environmental goals, and hard choices between objectives may have to be made.

Acknowledgments We thank the CRP6.3-gender studies and REDD-ALERT Project for funding the data collection, and the Women's Post-Doctoral Research Programme of the World Agroforestry Centre (ICRAF). We appreciate the comments and suggestions of Delia Catacutan, Carol Colfer, Guido Lüchters, and Ujjwal Pradjan on an earlier draft. We thank the anonymous reviewers for their constructive comments and valuable suggestions, as well as Diah Wulandari for administrative and logistical help during the data collection.

Open Access This article is distributed under the terms of the Creative Commons Attribution License which permits any use, distribution, and reproduction in any medium, provided the original author(s) and the source are credited.

\section{References}

Agarwal B (2001) Participatory exclusions, community forestry, and gender: an analysis for South Asia and a conceptual framework. World Dev 29(10):1623-1648

Akiefnawati R, Villamor GB, Zulfikar F et al (2010) Stewardship agreement to reduce emissions from deforestation and degradation (REDD): Lubuk Beringin's hutan desa as the first village forest in Indonesia. Int For Rev 12(4):349-360

Barber BM, Odean T (2001) Boys will be boys: gender, overconfidence, and common stock investment. Q J Econ 116(1):261-292

Behrman J, Meinzen-Dick R, Quisumbing A (2012) The gender implications of large-scale land deals. J Peasant Stud 39(1):49-79

Castella J-C, Trung TN, Boissau S (2005) Participatory simulation of land use changes in the northern mountains of Vietnam: the combined use of agent-based model, a role playing game, and geographic information system. Ecol Soc 10(1):27p

Coates J (2012) The hour between dog and wolf: risk taking, gut feelings and the biology of boom and bust. Penguin Press

Colfer CJP (2012) The complex forest: communities, uncertainty, and adaptive collaborative management. Routledge

Colfer CJP, Minarchek RD (2012) Women, men and forest research: a review of approaches, resources and methods for addressing gender. CIFOR, Bogor, Occasional Paper 80

Coomes OT, Burt GJ (1997) Indigenous market-oriented agroforestry: dissecting local diversity in western Amazonia. Agroforest Syst 37(1):27-44

D’ Aquino P, Le Page C, Bousquet F, Bah A (2003) Using self-designed role-playing games and a multi-agent system to empower a local decision-making process for land use management: the selfcormas experiment in Senegal. J Articif Societes Soc Simul 6(3)

DeFries RS, Rudel T, Uriarte M, Hansen M (2010) Deforestation driven by urban population growth and agricultural trade in the twenty-first century. Nat Geosci 3(3):178-181

Denton F (2002) Climate change vulnerability, impacts, and adaptation: why does gender matter? Gender Dev $10(2): 10-20$

Eckel C, De Oliveira A, Grossman PJ (2008) Gender and negotiation in the small: are women (perceived to be) more cooperative than men? Negotiation J 24(4):429-445

Ekadinata E, Vincent G (2011) Rubber agroforests in a changing landscape: analysis of land use/ cover trajectories in Bungo district, Indonesia. For Trees Livelihoods 20:3-14

Evans TP, Sun W, Kelley H (2006) Spatially explicit experiments for the exploration of land use decisionmaking dynamics. Int J Geogr Inf Sci 20(9):1013-1037 
Feldstein HS, Jiggins J (1994) Tools for the field: methodologies handbook for gender analysis in agriculture. Kumarian Press, Connecticut

Greiner R, Gregg D (2011) Farmers' Intrinsic motivations, barriers to the adoption of conservation practices and effectiveness of policy instruments: empirical evidence from northern Australia. Land Use Policy 28(1):257-265

Hemmati M, Röhr U (2009) Engendering the climate-change negotiations: experiences, challenges, and steps forward. Gender Dev 17(1):19-32

IFPRI (2012) Engendering agricultural research, development and extension. International Food Policy Research Institute

Lambin EF, Meyfroidt P (2011) Global land use change, economic globalization, and the looming land scarcity. P Natl A Sci 108(9):3465-3472

Le QB (2005) Multi-agent system for simulation of land use and land cover change: a theoretical framework and its first implementation for an upland watershed in the Central Coast of Vietnam. Center for Development Research. Bonn, University of Bonn. PhD in Geography

Macy MW, Willer R (2002) From factors to actors: computational sociology and agent-based modeling. Annu Rev Sociol 28(1):143-166

Mai Y, Mwangi E, Wan M (2011) Gender analysis in forestry research: looking back and thinking ahead. Int For Rev 13(2):245-258

Margono BA, Turubanova S, Zhuravleva I, Potapov P, Tyukavina A, Baccini A, Goetz S, Hansen MC (2012) Mapping and monitoring deforestation and forest degradation in Sumatra (Indonesia) using Landsat time series data sets from 1990-2010. Environ Res Lett 7(3):034010

Martial T, Helmi NE, Martius E (2012) Land and tree tenure rights on agroforestry (parak) system at communal land in West Sumatra, Indonesia. J Agric Ext Rur Dev 4(19):486-494

Miyamoto M (2007) Road construction and population effects on forest conversion in rubber villages in Sumatra, Indonesia. In: Dube YC, Schmithuesen F (eds) Cross-sectoral policy developments in forestry. CABI, Wallingford

Moreland RL, Levine JM (2002) Socialization and trust in work groups. Group Process Intergroup Relat $5(3): 185-201$

Neef A (2010) Resources, knowledge and innovation management in montane mainland southeast asia: what have we learned in the past decade. International Symposium on Sustainable land use and rural development in mountainous regions of Southeast Asia. Hanoi, Vietnam

Nelson V, Stathers T (2009) Resilience, power, culture, and climate: a case study from semi-arid Tanzania, and new research directions. Gend Dev 17(1):81-94

Otsuka K, Suyanto S, Sonobe T, Tomich TP (2001) Evolution of land tenure institutions and development of agroforestry: evidence from customary land areas of Sumatra. Agr Econ 25(1):85-101

Peach Brown H (2011) Gender, climate change and REDD+in the Congo Basin forests of Central Africa. Int For Rev 13(2):163-176

Plant S (2001) On the mobile: The effects of mobile telephones on social and individual life. Motorola

Quisumbing MAR (2001) Land, trees, and women: evolution of land tenure institutions in Western Ghana and Sumatra. Intl Food Policy Res Inst

Quisumbing AR, Otsuka K (2001) Land inheritance and schooling in matrilineal societies: evidence from Sumatra. World Dev 29(12):2093-2110

Robinson DT, Brown DG, Parker DC et al (2007) Comparison of empirical methods for building agent-based models in land use science. J Land Use Sci 2(1):31-55

Rothman KJ (2012) Epidemiology: an introduction, 2nd edn. Oxford University Press Inc, New York

Rudel TK, Defries R, Asner GP, Laurance WF (2009) Changing drivers of deforestation and new opportunities for conservation. Conserv Biol 23(6):1396-1405

Smajgl A, Brown DG, Valbuena D, Huigen M (2011) Empirical characterisation of agent behaviours in socioecological systems. Environ Model Softw 26:837-844

Stern DI (2004) The rise and fall of the environmental Kuznets curve. World Dev 32(8):1419-1439

Suyanto S, Tomich TP, Otsuka K (2001a) Land tenure and farm management efficiency: the case of paddy and cinnamon production in customary land areas of Sumatra. Aust J Agr Resour Econ 45(3):411-436

Suyanto S, Tomich TP, Otsuka K (2001b) Land tenure and farm management efficiency: the case of smallholder rubber production in customary land areas of Sumatra. Agrofor Syst 52:145-160

Szumilas M (2010) Explaining odds ratios. J Can Acad Child Adolesc Psychiatry 19(3):227-229

Terry G (2009) No climate justice without gender justice: an overview of the issues. Gend Dev 17(1):5-18

van Noordwijk M, Murdiyarso D, Hairiah K, Wasrin U, Rachman A, Tomich T (1998) Forest soils under alternatives to slash-and-burn agriculture in Sumatra, Indonesia. In: Schulte A, Ruhiyat D (eds) Soils of tropical forest ecosystems. Springer, Berlin

van Noordwijk M, Tata H, Xu J, Dewi S, Minang P (2012) Segregate or integrate for multifunctionality and sustained change through landscape agroforestry involving rubber in Indonesia and China. Nair PKR,Garrity D. Springer, Dordrecht 
Vanslembrouck I, Van Huylenbroeck G, Verbeke W (2002) Determinants of the willingness to participate in agri-environmental measures. J Agr Econ 50(3):489-511

Vieira Pak M, Castillo Brieva D (2010) Designing and implementing a role-playing game: a tool to explain factors, decision making and landscape transformation. Environ Model Softw 25(11):1322-1333

Villamor GB (2012) Flexibility of multi-agent system models for rubber agroforest landscapes and social response to emerging reward mechanisms for ecosystem services in Sumatra. University of Bonn Press, Indonesia Bonn

Villamor GB, van Noordwijk M (2011) Social role-play games vs individual perceptions of conservation and PES agreements for maintaining rubber agroforests in Jambi (Sumatra), Indonesia. Ecol Soc 16(3):27

Villamor GB, van Noordwijk M et al (2011) Diversity deficits in modelled landscape mosaics. Ecol Inform $6(1): 73-82$

Wossink GAA, van Wenum JH (2003) Biodiversity conservation by farmers: analysis of actual and contingent participation. Eur Rev Agr Econ 30:461-485

Zainudeen A, Iqbal T, Samarajiva R (2010) Who's got the phone? Gender and the use of the telephone at the bottom of the pyramid. New Media Soc 12(4):549-566

Zbinden S, Lee DR (2005) Paying for environmental services: an analysis of participation in Costa Rica's PSA Program. World Dev 33(2):255-272 